\title{
Misdiagnosing the Teacher Quality Problem
}

Richard Ingersoll

University of Pennsylvania, rmi@upenn.edu

Follow this and additional works at: https://repository.upenn.edu/cpre_policybriefs

Part of the Educational Sociology Commons, Education Policy Commons, Elementary Education and Teaching Commons, and the Secondary Education and Teaching Commons

\section{Recommended Citation}

Ingersoll, Richard. (2007). Misdiagnosing the Teacher Quality Problem. CPRE Policy Briefs.

Retrieved from https://repository.upenn.edu/cpre_policybriefs/35

View on the CPRE website.

This paper is posted at ScholarlyCommons. https://repository.upenn.edu/cpre_policybriefs/35

For more information, please contact repository@pobox.upenn.edu. 


\title{
Misdiagnosing the Teacher Quality Problem
}

\begin{abstract}
Few educational issues have received more attention in recent times than the problem of ensuring that our nation's elementary and secondary classrooms are all staffed with quality teachers. There is consensus that the quality of teachers and teaching matter--and undoubtedly are among the most important factors shaping the learning and growth of students. Moreover, there is consensus that serious problems exist with the quality of teachers and teaching in the United States. Beyond that, however, there appears to be little consensus and much disagreement--especially over what teacher quality entails and what the sources of, and solutions to, the problem might be.
\end{abstract}

This issue of CPRE Policy Briefs summarizes the findings on issues related to teacher quality in the chapter authored by me in the book, The State of Education Policy Research (Cohen, Fuhrman, Mosher, Eds., 2007). This report also draws on discussions that took place during a summer, 2006, policy briefing on teacher labor-market issues held in Chicago and sponsored by the Spencer Foundation.

In this brief, I will briefly discuss three related diagnoses and their attendant prescriptions: restrictive occupational entry barriers; teacher shortages; and underqualified/underprepared teachers. These diagnoses are not the only explanations for the problem of low quality of teachers and teaching. Nor are these views universally held--indeed, each is the subject of much contention--and proponents of one are at times opponents of another. But all are prominent views, all are part of the conventional wisdom as to what ails teaching, and all have had an impact on research, reform, and policy.

The thesis of this brief, however, is that each viewpoint is largely misinformed or misconstrued. My theoretical perspective is drawn from the sociology of organizations, occupations and work. My operating premise, drawn from this perspective, is that to fully understand issues of teacher quality requires examining the character of the teaching occupation and the nature of the organizations in which teachers work. A close look at the best data available from this perspective, I argue, shows that each of these views involves a wrong diagnosis and a wrong prescription. In the following sections, I review each of the above views and explain why each conveys an inaccurate explanation of--and solutions to-- the problems of quality plaguing the teaching occupation.

Disciplines

Educational Sociology | Education Policy | Elementary Education and Teaching | Secondary Education and Teaching

Comments

View on the CPRE website. 


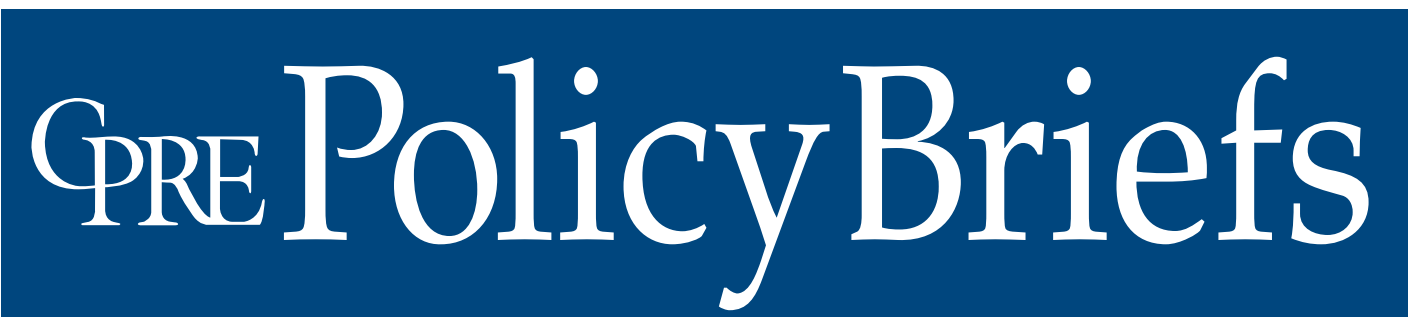

Reporting on Issues and Research in Education Policy and Finance

\section{Misdiagnosing}

\section{the Teacher Quality Problem}

\author{
By Richard M. Ingersoll
}

\section{Introduction}

Few educational issues have received more attention in recent times than the problem of ensuring that our nation's elementary and secondary classrooms are all staffed with quality teachers. There is consensus that the quality of teachers and teaching matter-and undoubtedly are among the most important factors shaping the learning and growth of students. Moreover, there is consensus that serious problems exist with the quality of teachers and teaching in the United States. Beyond that, however, there appears to be little consensus and much disagreement-especially over what teacher quality entails and what the sources of, and solutions to, the problem might be.

This issue of CPRE Policy Briefs summarizes the findings on issues related to teacher quality in the chapter authored by me in the book, The State of Education Policy Research (Cohen, Fuhrman, Mosher, Eds., 2007). This report also draws on discussions that took place during a summer, 2006, policy briefing on teacher labor-market issues held in Chicago and sponsored by the Spencer Foundation.

In this brief, I will briefly discuss three related diagnoses and their attendant prescriptions: restrictive occupational entry barriers; teacher shortages; and underqualified/underprepared teachers. These diagnoses are not the only explanations for the problem of low quality of teachers and teaching. Nor are these views universally held-indeed, each is the subject of much contention-and proponents of one are at times opponents of another. But all are prominent views, all are part of the conventional wisdom as to what ails teaching, and all have had an impact on research, reform, and policy.
The thesis of this brief, however, is that each viewpoint is largely misinformed or misconstrued. My theoretical perspective is drawn from the sociology of organizations, occupations and work. My operating premise, drawn from this perspective, is that to fully understand issues of teacher quality requires examining the character of the teaching occupation and the nature of the organizations in which teachers work. A close look at the best data available from this perspective, I argue, shows that each of these views involves a wrong diagnosis and a wrong prescription. In the following sections, I review each of the above views and explain why each conveys an inaccurate explanation of - and solutions tothe problems of quality plaguing the teaching occupation.

\section{Occupational Entry Overly Restrictive?}

There is much debate over the qualifications deemed necessary for entry into, and success in, the teaching occupation. How much and what kinds of preparation, training and certification should we require to yield well-qualified classroom teachers? In short, what kinds of teacher qualifications beget teacher and teaching quality? On one side are those who argue that a primary source of lowquality teaching has been a lack of depth, rigor and breadth in pre-service training and certification (e.g., National Commission on Teaching and America's Future, 1996, 1997; Interstate New Teacher Assessment and Support Consortium, 1992). This viewpoint (to which I will return later) holds that we simply have had too few requirements and standards that are too low. Accordingly, proponents of this view seek to upgrade and expand the education, training, and certification standards required of new teachers.
February 2007 RB-49

Graduate School

of Education

University of

Pennsylvania

\section{Consortium for Policy Research in Education}

University

of Pennsylvania

Teachers College, Columbia University

Harvard University

Stanford University

University of Michigan

University of Wisconsin-Madison

Northwestern University 
On the other side are those who hold that entry into the teaching occupation is already plagued by unusually restrictive and unnecessary rigid bureaucratic entry barriers (e.g., Finn et al., 1999; Hanushek \& Rivkin, 2004; Ballou, 1996; Walsh, 2001; U.S. Department of Education, 2002). From this deregulationist viewpoint, traditional teacher training and state certification requirements are akin to monopolistic practices. These critics argue that there is no solid empirical research documenting the value of such entry requirements. These regulations, such critics charge, are less motivated by an interest in protecting the public and really are about protecting the selfinterest of key constituencies within the education system. As a result, this view holds, large numbers of high-quality candidates are discouraged from getting into the occupation. By doing away with these impediments, this argument concludes, schools finally could recruit the kinds and numbers of candidates they deem best and solve the quality problems that plague the teaching force.

There are a number of variants of the antirestrictive-entry perspective. One of the more popular variants favors a training model analogous to that dominant in higher education. The pre-service preparation of professors often includes little formal training in instructional methods. Similarly, from this viewpoint, having an academic degree in a subject is sufficient to be a qualified secondary school teacher in that subject. From this viewpoint, content or subject knowledge - knowing what to teach-is considered of primary importance for being a qualified teacher. Formal training in teaching and pedagogical methods-knowing how to teach-is considered less necessary (e.g., Finn et al., 1999).

Another variant of the anti-restrictiveentry perspective is motivated by concern for demographic diversity within the teaching force. From this viewpoint, teaching's entry requirements result in reduced numbers of minority candidates entering the occupation, either because the requirements are themselves racially or ethnically biased, or because they screen out otherwise worthwhile candidates who are unable to clear particular hurdles because of an underprivileged background (e.g., Villegas \& Lucas, 2004).

Proponents of these various anti-restrictive-entry perspectives have pushed a range of
The research reported in this brief was conducted by the Consortium for Policy Research in Education (CPRE) and funded by the Institute of Education Sciences, United States Department of Education, under Grant No. R308A960003. Opinions expressed in this Brief are those of the authors and do not necessarily reflect the views of the Institute of Education Sciences, the United States Department of Education, CPRE, or its institutional members.

initiatives, all of which involve a loosening of the traditional entry gates. Examples include alternative certification programs, whereby a college graduate can postpone formal education training, obtain an emergency teaching certificate, and begin teaching immediately; and Peace Corps-like programs, such as Teach For America, which seek to lure the "best and brightest" into understaffed schools. It also is important to note that proponents of these alternative routes into the occupation claim the same rationale as those who propose to upgrade existing entry standards and programs, that is, enhancing recruitment of highquality candidates into teaching.

To be sure, there are at least two problems with existing teaching entry requirements. First, such requirements sometimes keep out capable candidates. Not everyone may need such qualifications to be a good teacher. There are no doubt some individuals who are able to teach anything well, regardless of how few credentials they have. Moreover, especially in the absence of subsequent commensurate rewards, otherwise qualified candidates might be discouraged by the initial commitment and costs incurred because of these entry hurdles. According to some, historically this has been the case in teaching. Attempts to upgrade the status of the occupation through more rigorous preparation and licensing standards or more selective entry gates appear to have often resulted in decreases in male entrants who were eligible for, and more attracted to, other occupations with better rewards (Strober \& Tyack, 1980).

Second (and conversely), entry requirements sometimes do not keep out some who ought not be in this particular line of work. That is, having obtained credentials and completed exams does not guarantee that an individual will be a good-quality teacher, or even a qualified teacher. There are no doubt some 
individuals who are unable to teach anything well, regardless of how many hurdles they have passed and credentials they have obtained.

But, these two problems are true in all occupations and professions. For example, there are otherwise highly capable individuals who cannot practice law because they did not complete a three-year law school program and pass a state bar exam. Alternatively, there are individuals who did complete law school and did pass a bar exam, but who ought not be practicing lawyers.

It is useful to place teaching's entry and training requirements, and the arguments for and against, in context. The restrictiveness of occupational entry requirements is relative; when evaluating the norms and rules governing a particular occupation, the question must always be posed-compared to what?

\section{A Cross-National Comparison}

One useful comparison is cross-national. Compared to the United States, how restrictive and rigorous is entry into the teaching occupation in other developed nations? Recent comparative studies we have undertaken indicate that the requirements to become a teacher in the United States are not burdensome or restrictive compared to Asian nations, such as Korea, Japan, Thailand, Singapore and Hong Kong (Ingersoll, 2007). Similarly, another recent cross-national study of the United States, Australia, England, Japan, Korea, Netherlands, Hong Kong, and Singapore found that the filters and requirements embedded in the process of becoming a teacher in the United States are among the least rigorous, arduous and lengthy (Wang et al., 2003). Further cross-national comparisons are warranted.

Another useful comparison is cross-occupational. Sociologists of work and occupations traditionally have classified teaching as a relatively complex form of work, characterized by uncertainty, intangibility, and ambiguity, and requiring as high a degree of initiative, thought, judgment, and skill to perform at a high level, as do some of the traditional professions (e.g., Bidwell, 1965; Lortie, 1975; Kohn \& Schooler, 1983).

However, sociologists also traditionally have characterized teaching as an easy-in /easy-out occupation. Compared to many other occupations and, in particular compared to the traditional professions, this perspective holds that teaching has a relatively low entry bar and a relatively wide entry gate (Etzioni, 1969). This stands in stark contrast to the deregulation perspective's claim that entry into teaching is overly restrictive.

In his classic study of the teaching occupation, Lortie (1975) drew attention to a number of mechanisms that facilitate ease of entry. First, teacher training is relatively accessible. Beginning, in the early part of the 20th century, the states created large numbers of lowcost, dispersed and nonselective teacher-training institutions. Another aspect that facilitates entry is what Lortie calls "contingent schooling"- training programs geared to the needs of recipients and accessible to those already teaching. Persisters can increase their investment in occupational training, while others can choose to restrict their commitment to the minimum required. Teaching also has a relatively wide "decision range"; individuals can decide to become teachers at any number of points in their life span. Finally, most of those who desire to enter the teaching occupation are free to do so-individuals choose the occupation, not vice versa-a characteristic Lortie labeled the "subjective warrant." In contrast, the opposite prevails in many occupations and most traditional professions. Especially in the latter, occupational gatekeepers have a large say in choosing new members and not all who desire to enter are allowed to do so.

\section{Scrutinizing the Occupation}

Ironically, although teaching's entry training and licensing requirements are lower than those for many other occupations in the United States and lower than in some other nations, they appear to be subject to far more scrutiny than those in other occupations. There is an extensive body of empirical research, going back a couple of decades, devoted to evaluating the effects of teachers' qualifications on student performance. Accurately isolating and capturing the effects of teachers' qualifications on their students' achievement is difficult and, not surprisingly, the results from this literature are often contradictory (for a recent review, see Allen, 2003). But, a number of studies have indeed found teacher education and training of one sort or another, to be significantly related to 
increases in student achievement. For example, in a review of 60 empirical studies on the effects of teacher education, Greenwald, Hedges, and Laine (1996) concluded that teachers' degree levels consistently showed "very strong relations with student achievement" . . . in "a wide variety of studies over a three decade period" (pp. 284-285). Some studies look closely at the amount and effects of subject-specific teacher education. For example, in a multilevel analysis of 1992 NAEP data, Raudenbush, Fotiu, and Cheong (1999) found teacher education in mathematics (as measured by a major in math or in math education) to be "consistently positively and highly significantly related to math proficiency" in eighth-grade students. Similarly, an analysis of 2000 NAEP data found that eighth-grade students whose math teachers had a regular teaching certificate in math, or had a major or minor in math or math education scored significantly higher on the eighthgrade math test (Greenberg, Rhodes, Ye, \& Stancavage, 2004).

Scrutiny of the value added by entry requirements is, of course, useful from the perspective of the public interest. But, such scrutiny also appears to be highly selective. It can be useful to place this research itself in a cross-occupational comparison.

Typically for most occupations, there is little or no empirical research done assessing the value added of practitioners having a particular credential, license or certification (Kane, 1994; American Educational Research Association, American Psychological Association, National Council on Measurement in Education, 1999). Such research can be difficult to undertake. For instance, if licensure is mandatory in an occupation, it is impossible to compare the performance of those licensed with those unlicensed. Nevertheless, occupational entry requirements, whether by precedent or by law, are common. For example, almost all universities require a doctorate degree for fulltime academic positions. There is, of course, a growing secondary labor market in academia in which those without doctoral degrees are hired for various instructional or research positions, usually as non-tenure-track employment. However, there are very few if any examples of "professor effect" literature that examines whether professors' qualifications have a positive effect on outcomes such as student achievement or on research quality (for a review, see Pascarella \& Terenzini, 1991). In other words, in academia as in most occupations and professions, it appears that typically it is taken as a given that particular credentials are necessary to practice particular kinds of work. Hence, from an occupational and organizational perspective, the interesting research question is not solely, Do qualifications matter for teachers? But others arise: Why do so many find this an important question? Is teaching held to up to more scrutiny and skepticism than other occupations and, if so, why? Is there a double standard and, if so, is it justified?

Regardless of their impact on recruitment, the data suggest that increased occupational regulation or deregulation, alone, will not solve the problem of ensuring a quality teacher in every classroom if it does not also address the issue of retention-the subject of the next section.

\section{Teacher Shortages}

A second and related explanation for the problem of low-quality teaching in American schools focuses on teacher shortages. In this view, the main source of the problem is that the supply of new teachers is insufficient to keep up with the demand. Restrictive entry requirements may exacerbate this condition, but the root of this gap, it is widely believed, is a dramatic increase in the demand for new teachers primarily resulting from two converging demographic trends-increasing student enrollments and increasing teacher retirements due to a "graying" teaching force. Shortfalls of teachers, this argument continues, have meant that many school systems have not been able to find qualified candidates to fill their openings, inevitably resulting in the hiring of underqualified teachers and ultimately lowering school performance.

The prevailing policy prescription and response to school staffing problems has been to attempt to increase the quantity of teachers supplied through a wide range of recruitment initiatives. Some of these involve a loosening of entry requirements; some do not. There are career-change programs, such as the federally funded Troops to Teachers program, which aim to entice professionals or in other careers to become teachers. Some school districts have instituted recruiting teaching candidates from other countries. Financial incentives, such as signing bonuses, student loan forgive- 
ness, housing assistance, and tuition reimbursement all have been used to aid recruitment (Hirsch, Koppich, \& Knapp, 2001).

The data, however, raise serious doubts for the success of these kinds of initiatives. In my own research, I have shown that the main source of school staffing problems derives not from shortages - in the sense of too few new candidates being produced-but rather that too many teachers leave their jobs (Ingersoll, 2001, 2003b) early or midcareer. Most of the demand for new teachers is not driven by student enrollment or teacher retirement increases, but from pre-retirement teacher turnover.

As an occupation, teaching has higher turnover rates than a number of higher-status professions (such as professors and scientific professionals), about the same as other traditionally female occupations (such as nurses) and less turnover than some lower-status, lower-skill occupations (such as clerical workers). But, it is important to recognize that teaching is also a relatively large occupation. Teachers represent $4 \%$ of the entire civilian workforce. There are, for example, more than twice as many elementary and secondary teachers as there are registered nurses, and there are five times as many teachers as there are either lawyers or professors. The sheer size of the teaching force combined with its levels of annual turnover mean that there are large numbers of teachers in some kind of job transition each year. For example, the data show that over the course of the 1999-2000 school year, well over 1 million teachersalmost a third of this large workforce-moved into, between, or out of schools. The image that these data suggest is one of a "revolving door." The latter is a major, but unheralded, factor behind the difficulties many schools have in ensuring that their classrooms are staffed with qualified teachers.

Of course, not all teacher turnover is negative. Some degree of employee turnover is normal and beneficial in any workplace. Too little turnover of employees is tied to stagnancy in organizations; effective organizations usually both promote and benefit from a limited degree of turnover by eliminating lowcaliber performers and bringing in "new blood" to facilitate innovation. But, a "revolving door" is costly. In the corporate sector it has long been recognized that high employee turnover means substantial recruitment and training costs and is both the cause and effect of productivity problems (e.g., Price, 1977, 1989; Hom \& Griffeth, 1995).

Some of the benefits, costs, and consequences of turnover are more easily measured and quantified than others. In contrast to the corporate sector, however, there has been very little attention paid to the costs and consequences of employee turnover in education. One exception was a recent attempt to quantify the costs of teacher turnover in Texas. This study concluded these costs run into the hundreds of millions of dollars to the state each year. (Texas Center for Educational Research, 2000). Another notable recent effort was an attempt to quantity the costs of turnover in an analysis of the costs and benefits of induction for beginning teachers in California (Villar, 2004).

Teaching also is an occupation that loses many of its newly trained members very early in their careers. The data indicate that as many as half of those trained to be teachers never enter teaching, and that $40-50 \%$ of those who do enter teaching leave the occupation altogether in the first five years on the job. Moreover, the data tell us that the overall amount of turnover accounted for by retirement is relatively minor when compared with that resulting from other causes, such as job dissatisfaction and teachers seeking better jobs or other careers. Together, these latter two reasons count as the most prominent source of turnover and account for almost half of all departures each year. Of those who leave because of job dissatisfaction, most link their departures to several key factors: low salaries, lack of support from the school administration, student discipline problems, and lack of influence over school decision-making.

\section{Impact of Mentoring}

In a followup analysis of the data, we explored the impact of mentoring and induction programs on the turnover of new teachers. After controlling for the background characteristics of teachers and schools, we found a strong link between participation by beginning teachers in induction and mentoring programs and their likelihood of moving or leaving after their first year on the job (Smith \& Ingersoll, 2003). The data showed that the turnover of first-year, newly hired, inexperienced teachers, who did not participate in any 
induction and mentoring programs was $40 \%$. In contrast, after controlling for the background characteristics of teachers and schools, the turnover of beginning teachers who received a basic package of induction (had a mentor from their same field; had common planning time or regularly scheduled collaboration with other teachers in their field; had regular or supportive communication with their principal, other administrators, or department chair; participated in a seminar for beginning teachers) was $27 \%$. Twenty-six percent of beginning teachers received just these four components. Finally, a very small number (less than $1 \%$ of beginning teachers in 1999-2000) experienced a comprehensive induction package that included the above four components, plus three more: participated in an external network; had a reduced number of course preparations; assigned a teacher's aide. Participation in these activities, collectively, had a very large and statistically significant impact; the probability of a departure at the end of their first year for those getting this package was less than half than those who participated in no induction activities.

These findings have large implications for current policy-they suggest prescriptions must focus less on recruitment and more on retention. In short, recruiting more teachers will not solve the teacher crisis if large numbers of those teachers then leave. The image that comes to mind is of a bucket rapidly losing water because of holes in the bottom. Pouring more water into the bucket will not be the answer if the holes are not first patched.

Of course, nothing in the data suggests plugging these holes will be easy or inexpensive. But, the data do make clear that schools are not simply victims of inexorable demographic trends, and there is a significant role for the management and organization of schools in both the genesis of, and the solution to, school staffing problems. Improving workplace conditions in our schools, as discussed above, would contribute to lower rates of teacher turnover, which in turn would slow down the revolving door, help ensure that every classroom is staffed with a qualified teacher, and ultimately increase the performance of schools.

\section{The Problem of Underqualified Teachers}

A third prominent explanation of lowquality teaching focuses on the adequacy of the qualifications of prospective teachers. In this view, as noted earlier, a major source of low-quality teaching is low-quality pre-service education, training, and certification standards (e.g., National Commission on Teaching and America's Future, 1996, 1997). In contrast to the deregulation perspective, this group seeks to upgrade the training and certification standards traditionally required of new teachers. In response, reformers in many states have pushed tougher certification requirements and more rigorous coursework requirements for teaching candidates.

Upgrading teacher preparation programs and teacher certification standards certainly may be necessary and helpful. However, like many similarly worthwhile reforms, these efforts alone will also not solve the problem of underqualified teachers because they do not address some key causes. One of the least recognized of these causes is the problem of outof-field teaching - teachers being assigned to teach subjects that do not match their training or education. From a policy perspective, this is a crucial issue because highly qualified teachers may become highly unqualified if they are assigned to teach subjects for which they have little training or education.

In my own research, I have found that outof-field teaching is a chronic and widespread problem. For example, about one third of all secondary (grades 7-12) math classes are taught by teachers who do not have either a major or a minor in math, or in a related discipline such as physics, statistics, engineering, or math education. Almost one quarter of all secondary-school English classes are taught by teachers who are not certified in English. Some out-of-field teaching takes place in well over half of all secondary schools in the United States in any given year. Each year over one fifth of the public teaching force grades 712 does some out-of-field teaching (Ingersoll, 1999).

Typically, policymakers and analysts have assumed that the problem of out-of-field teaching is a result of teacher shortages. The 
conventional wisdom holds that shortfalls in the number of available teachers have led many school systems to resort to assigning teachers to teach out of their fields (National Commission on Teaching and America's Future, 1996, 1997). Recruitment difficulties are clearly factors, but the data show that outof-field teaching cannot be explained entirely by teacher shortages. The data show, for example, high levels of out-of-field teaching exist in fields, such as English and social studies, that have long been known to have surpluses.

\section{Out-of-Field Teaching}

Rather than deficits in the qualifications and quantity of teachers, the data point in another direction-out-of-field teaching is really an issue of human-resource management and mismanagement. The data tell us that decisions concerning the allocation of teaching assignments usually are the prerogative of school principals (Ingersoll, 2003a). School managers are charged with the oftendifficult task of providing a broad array of programs and courses with limited resources, limited time, a limited budget, and a limited teaching staff (Delany, 1991). In this context, principals may find that assigning teachers to teach out of their fields often is more convenient, less expensive and less time-consuming than the alternatives. For example, rather than find and hire a new part-time science teacher to teach two sections of a newly state-mandated science curriculum, a principal may find it more convenient to assign a couple of English and social studies teachers to "cover" the science sections. If a teacher suddenly leaves in the middle of a semester, a principal may find it faster and cheaper to hire a readily available, but not fully qualified, substitute teacher, rather than conduct a formal search for a new teacher. When faced with a tough choice between hiring an unqualified candidate for a science teacher position or doubling the class size of one of the fully qualified science teachers in the school, a principal might opt for the former choice, resulting in a smaller class, but taught by a lesser-qualified teacher. If a fulltime music teacher is under contract, but student enrollment is sufficient to fill only three music classes, the principal may find it both necessary and cost-effective in a given semester to assign the music teacher to teach two classes in English, in addition to the three classes in music, to employ the teacher for a regular full-time complement of five classes per semester. All of these managerial choices to misassign teachers may save time and money for the school, and ultimately for the taxpayer, but they are not cost-free. They are a large, and until recently, under-recognized source of the problem of underqualified teachers in classrooms.

Understanding the reasons behind the problem of underqualified teaching is important because of their implications for solving the problem. Most recent federal, state and local teacher policies and initiatives have focused on two general approaches to ensure that all classrooms are staffed with qualified teachers: upgrading the qualifications of teachers; and increasing the quantity of teachers supplied. These kinds of initiatives also are emphasized in No Child Left Behind. The Title II portion of the Act, for example, specifically focuses on enhancing teacher training and teacher recruitment in its list of methods approved for funding.

Underlying these kinds of methods is what might be called a teacher deficit perspectivethe assumption that the primary source of underqualified teachers in schools lies in deficits among the teachers themselves - their numbers, preparation, knowledge, ability, and licensing, etc. Of course, increasing teacher recruitment and upgrading teacher preparation standards can be useful first steps. But, the above methods do not address the ways schools themselves contribute to the problem of being staffed with underqualified teachers. The data tell us that solutions to the problem of out-of-field teaching also must look to how schools are managed and how teachers are utilized once on the job. In short, recruiting thousands of new candidates and providing them with rigorous preparation will not solve the problem if large numbers of those teachers continue to be assigned to teach subjects other than those for which they were prepared.

This problem presents a thorny policy dilemma. Solving the problem of underqualified teachers requires changes to the internal management of schools. If legislation results in increased accountability for teachers without commensurate changes in the way schools are managed, it could lead to a classic organizational problem-employees blamed for 
things over which they have no control-and end up exacerbating the very teacher quality problems the legislation seeks to solve.

If assigning teachers to teach out of their fields has been a prevalent administrative practice for decades because it is more efficient and less expensive than the alternatives, then its elimination will not be easily accomplished simply by legislative fiat. In order to meet the goal of ensuring all students are provided with qualified teachers, it will be necessary to rethink how districts and schools go about managing human resources.

\section{Rethinking Teacher Staffing}

One area that will need rethinking is how school staffing decisions are made and who makes them. As mentioned, the data tell us that, unlike in higher education, elementary and secondary teacher staffing decisions have traditionally followed a top-down model: school principals make their decisions and teachers typically have little say over which courses they are assigned to teach. As earlier examples illustrate, these staffing decisions often involve difficult tradeoffs and sometimes lead to out-of-field teaching. In contrast, districts and schools could implement mechanisms of school-based management where such decision-making is shared with those who must live with, and may be held accountable for, the consequences - the faculty. Similarly, states could provide training and assistance to district and school administrators in how to better balance tradeoffs between organizational, budgetary, and educational needs-something that has been largely neglected in the past.

Another area that will need rethinking concerns teacher employment practices. Meeting standards for qualified teachers will be more difficult in some settings than others. Rural school districts, for example, tend to have smaller secondary schools with smaller faculties. As a result, the data suggest, teachers in those schools more often are required to be generalists and to teach a variety of subjects regardless of their background. In such settings, states might consider the use of itinerant teachers, where schools share the use of teachers with preparation in a specialty. This could include the employment of retired teachers. Similarly, states could fund technology initia- tives to provide rural and hard-to-staff schools with access to teachers with preparation in a specialty.

A third area that will need rethinking concerns the provision of administrative support for teachers. The data indicate that beginning teachers are more likely than veteran teachers to be given out-of-field assignments. Disproportionately burdening newcomers probably contributes to the problem of high levels of beginning teacher attrition. Moreover, the data indicate that when teachers are misassigned they are largely left to their own devices. In situations where it may be difficult to eliminate entirely out-of-field teaching, districts could prohibit out-of-field assignments for new teachers, provide funding for additional coursework for misassigned teachers, or provide funding for veteran teachers to mentor, assist or team teach with misassigned teachers.

The lesson is clear: If we want to ensure that all classrooms are staffed by qualified teachers, we will need to change the way that schools operate and that teachers are managed. In short, upgrading the quality of teaching will require upgrading the quality of the teaching job.

\section{About the Author}

Richard M. Ingersoll is Professor of Education and Sociology at the University of Pennsylvania, Philadelphia. Dr. Ingersoll's research is concerned with the character of elementary and secondary schools as workplaces, teachers as employees, and teaching as a job. He has published numerous articles, reports, and pieces on the management and organization of schools, the problem of underqualified teachers, the debate over school accountability, the problems of teacher turnover and teacher shortages, the status of teaching as a profession, and the degree to which schools are centralized or decentralized and that impact on school performance. He has been published widely on the problems of teacher shortages and underqualified teachers. 


\section{References}

Allen, M. (2003). Eight questions on teacher preparation: What does the research say? Denver, CO: Education of the States.

American Educational Research Association, American Psychological Association, National Council on Measurement in Education (1999). Standards for educational and psychological testing. Washington, DC: author.

Ballou, D. (1996). Do public schools hire the best applicants? Quarterly Journal of Economics, 111(1), 97-133.

Delany, B. (1991). Allocation, choice and stratification within high schools: How the sorting machine copes. American Journal of Education, 99(2), 181-207.

Etzioni, A. (1969). (Ed.) The semi-professions and their organizations: Teachers, nurses and social workers. New York: Free Press.

Finn, C., Kanstoroom, M., \& Petrilli, M. (1999). The quest for better teachers: Grading the states. Washington, DC: Thomas B. Fordham Foundation.

Greenwald, R., Hedges, L., \& Laine, R. (1996). The effect of school resources on student achievement. Review of Educational Research, 66(3), 361-396.

Guarino, C., Santibanez, L., Daley, G., \& Brewer, D. (2004). A review of the research literature on teacher recruitment and retention. Santa Monica, CA: RAND Corporation. Retrieved February 20, 2007, from http://www.rand.org/publications/TR/TR164/.

Hanushek, E., \& Rivkin, S. (2004). How to improve the supply of high quality teachers. In Diane Ravitch (Ed.), Brookings Papers on Education Policy. Washington, DC: Brookings Institution.

Hirsch, E, Koppich, J., \& Knapp, M. (2001). Revisiting what states are doing to improve the quality of teaching: An update on patterns and trends. Center for the Study of Teaching and Policy, University of Washington.

Hom, P., \& Griffeth, R. (1995). Employee turnover. Cincinnati: South-Western Publishing.
Ingersoll, R. (1999). The problem of underqualified teachers in American secondary schools. Educational Researcher, 28, 26-37. Retrieved February 20, 2007, from http://www.gse.upenn. edu/faculty_research/docs/ER-RMI-1999.pdf.

Ingersoll, R. (2001). Teacher turnover and teacher shortages: An organizational analysis. American Educational Research Journal, 38(3), 499-534. Retrieved February 20, 2007, from http://www.gse.upenn.edu/faculty_research/Teach erTurnoverTeacherShortages-RMI-Fall-2001.pdf.

Ingersoll, R. (2003a) Who controls teachers' work?: Power and accountability in America's schools. Cambridge, MA: Harvard University Press. Retrieved February 20, 2007, from http://www.hup.harvard.edu/catalog/INGWHO.ht $\mathrm{ml}$.

Ingersoll, R. (2003b). Is there really a teacher shortage? The Consortium for Policy Research in Education, University of Pennsylvania. Retrieved February 20, 2007, from http://www.gse.upenn.edu/faculty_research/Sho rtage-RMI-09-2003.pdf.

Ingersoll, R. (2004a). Why some schools have more underqualified teachers than others. In Diane Ravitch (Ed.), Brookings Papers on Education Policy (pp. 45-88). Washington, DC: Brookings Institution. http://www. gse.upenn.edu/faculty_research/docs/BPEPRMI-2004.pdf.

Ingersoll, R. (2004b). Four myths about America's teacher quality problem. In Mark Smylie and Debra Miretzky (Eds.), Developing the teacher workforce, The 103rd Yearbook of the National Society for the Study of Education (pp 133). Chicago: National Society for the Study of Education. Retrieved February 20, 2007, from http://www.gse.upenn.edu/faculty_research/doc s/FourMyths.pdf.

Ingersoll, R. (2007). A Comparative study of teacher preparation and qualifications in six nations. Forthcoming report to be published by the Consortium for Policy Research in Education, University of Pennsylvania.

Interstate New Teacher Assessment and Support Consortium. (1992). Model standards for beginning teacher licensing, assessment and development. Washington, DC. Council of Chief State School Officers. 
Johnson, S., \& Birkeland, S. (2003). Pursuing a sense of success: New teachers explain their career decisions. American Educational Research Journal, 40(3), 581-617.

Kane, M. (1994). Validating interpretive arguments for licensure and certification examinations. Evaluation \& The Health Professions, 17(2), 133-159.

Kohn, M., \& Schooler, C. (1983). Work and personality. Norwood, NJ: Ablex.

Lortie, D. (1975). School teacher. Chicago: University of Chicago Press.

National Commission on Teaching and America's Future. (1996). What matters most: Teaching for America's future. New York: NCTAF.

National Commission on Teaching and America's Future. (1997). Doing what matters most: Investing in quality teaching. New York: NCTAF.

Pascarella, E., \& Terenzini, P. (1991). How college affects students: Findings and insights form twenty years of research. San Francisco: JosseyBass.

Price, J. (1977). The study of turnover. Ames, IA: Iowa State University Press.

Price, J. (1989). The impact of turnover on the organization. Work and Occupations, 16, 461473.

Smith, T., \& Ingersoll, R. (2004). What are the effects of induction on beginning teacher turnover? American Educational Research Journal, 41, 681-714.

Strober, M., \& Tyack, D. (1980). Why do women teach and men manage? Signs, 5, 499. 500 .

Texas Center for Educational Research. (2000). The cost of teacher turnover. Austin, TX: Texas State Board for Educator Certification.

U.S. Department of Education, Office of Postsecondary Education. (2002). Meeting the highly qualified teachers challenge: The secretary's annual report on teacher quality. Washington, DC.
Villar, A. (2004). Measuring the benefits and costs of mentor-based induction. Paper presented at the Annual Meeting of the American Educational Research Association. San Diego.

Villegas, A., \& Lucas, T. (2004). Diversifying the teacher workforce. In Mark Smylie and Debra Miretsky (Eds.), The 103rd Yearbook of the National Society for the Study of Education. (Pp 70-104). Chicago: National Society for the Study of Education.

Walsh, K. (2001). Teacher certification reconsidered. Abell Foundation.

Wang, A., Coleman, A., Coley, R., \& Phelps, R. (2003). Preparing teachers around the world. Princeton, NJ: Educational Testing Service. 


\section{Recent CPRE Publications}

The following is a list of selected publications reporting on the issue of recruiting and retaining qualified teachers-a key factor for improving student achievement and a fundamental problem facing schools in the United States. CPRE researchers examine organizational factors and conditions in schools leading to school staffing problems-such as teacher job dissatisfaction and compensation issues.

Visit www.cpre.org for more information on any of the following products published by the Consortium for Policy Research in Education. To obtain journal articles, please contact the organization and/or publisher directly.

Borman, G., \& Kimball, S. (2005). Teacher quality and educational quality: Do teachers with higher standards-based evaluation ratings close student achievement gaps? The Elementary School Journal, 106(1), 3-20.

Gallagher, A.H. (2004). Vaughn Elementary's innovative teacher evaluation system: Are teacher evaluation scores related to growth in student achievement? Peabody Journal of Education, 79(4), 79-107.

Heneman, H.G. III, \& Milanowski, A. (2004). Alignment of human resource practices and teacher performance competency. Peabody Journal of Education, 79(4), 108-125.

Hill, H., Rowan, B., \& Ball, D.L. (2005). Effects of teachers' mathematical knowledge for teaching on student achievement. American Educational Research Journal, 42(2), 371-406.

Ingersoll, R. (2003). Is there really a teacher shortage? Co-Published with the Center for the Study of Teaching and Policy. Philadelphia: The Consortium for Policy Research in Education.

Ingersoll, R. (2003). Out-of-field teaching and the limits of teacher policy. Co-Published with the Center for the Study of Teaching and Policy. Philadelphia: The Consortium for Policy Research in Education.

Ingersoll, R. (2003). Who controls teachers' work? Power and accountability in America's schools. Cambridge, MA: Harvard University Press.
Ingersoll, R., \& Kralik, J. (2004). The impact of mentoring on teacher retention: What the research says. Denver: Education Commission of the States

Kimball, S., Heneman, H.G. III, \& Kellor, E. (2003). Pensions for teachers: Possible changes and implications. (CPRE UW- Working Paper Series, No. TC-03-09). Philadelphia: Consortium for Policy Research in Education.

Milanowski, A., \& Heneman, H.G. III (2003). Continuing assessment of teacher reactions to a standards-based teacher evaluation system. Journal of Personnel Evaluation in Education, 17(2), 173-195.

Odden, A. (2003). An early assessment of comprehensive teacher compensation change plans. In D. Monk and M. Plecki (Eds.), School finance and teacher quality: Exploring the connections. 2003 Annual Yearbook of the American Education Finance Association (pp. 209228). Philadelphia: Eye on Education.

Odden, A., Kelley, C., Heneman, H.G. III, \& Milanowski, A. (2001). Enhancing teacher quality through knowledge and skills-based pay. (CPRE Research Brief No. RB-34). Philadelphia: The Consortium for Policy Research in Education. 


\section{Nondiscrimination Statement}

The University of Pennsylvania values diversity and seeks talented students, faculty, and staff from diverse backgrounds. The University of Pennsylvania does not discriminate on the basis of race, sex, sexual orientation, religion, color, national or ethnic origin, age, disability, or status as a Vietnam era veteran or disabled veteran in the administration of educational policies, programs, or activities; admissions policies, scholarships, or loan awards; and athletic or University-administered programs or employment. Questions or complaints regarding this policy should be directed to Executive Director, Office of Affirmative Action, 1133 Blockley Hall, Philadelphia, PA 19104-6021 or 215-898-6993 (Voice) or 215-898-7803 (TDD).

\section{About CPRE}

The Consortium for Policy Research in Education (CPRE) studies alternative approaches to education reform in order to determine how state and local policies can promote student learning. Currently, CPRE's work is focusing on accountability policies, efforts to build capacity at various levels within the education system, methods of allocating resources and compensating teachers, instructional improvement, finance, and student and teacher standards. The results of this research are shared with policymakers, educators, and other interested individuals and organizations in order to promote improvements in policy design and implementation.

CPRE unites seven of the nation's leading research institutions to improve elementary and secondary education through research on policy, finance, school reform, and school governance. Members of CPRE are the University of Pennsylvania, Teachers College Columbia University, Harvard University, Stanford University, the University of Michigan, Northwestern University, and the University of WisconsinMadison.

CPRE Policy Briefs are published by CPRE. To learn more about CPRE research or publications, please call 215-573-0700 or access CPRE publications at www.cpre.org; www.wcer. wisc.edu/cpre/; or www.sii.soe.umich.edu.
Graduate School of Education University of Pennsylvania

3440 Market Street, Suite 560

Philadelphia, PA 19104-3325
NON PROFIT

U.S. POSTAGE

PAID

PERMIT NO. 2563

PHILADELPHIA, PA 